\title{
One speaker, two languages: Learning opportunities in the mathematics classroom
}

\author{
Núria Planas
}

\begin{abstract}
The data reported in this article come from a large project whose goal was to explore how Latin American students in Catalonia, Spain use their two languages—Spanish and Catalan— to support their learning of mathematics in small groups with other students who are Spanish- or Catalandominant. For 5 years, lessons from bilingual mathematics classrooms in three public secondary schools were video-recorded and transcribed. In the presentation of findings, I discuss three language practices that emerged from the analyses of several classroom instances as follows: (1) caution with mathematical vocabulary, (2) invention of terms, and (3) word-for-word translation. One example is chosen to represent each practice and some of its situated effects. The first two examples support the view that the experience of language difficulties, either real or presumed, contributes to generating opportunities that may be beneficial to mathematics learning. The third example, where the focus on the mathematics is hindered, points to a contrasting finding. Unlike other studies in the field, which have reported the difficulties and obstacles that arise in learning and teaching due to bilingualism in the classroom, I propose a change of focus through the conceptualization of language as a potential for thinking and doing, and particularly for learning and teaching mathematics.
\end{abstract}

\section{Keywords}

Bilingual students. Mathematics learning opportunities . Language-as-resource . Classroomdata

1 Introduction

In several parts of the world, mathematics teaching and learning take place in languages other than the students' dominant languages. Mathematics education research, meanwhile, has acknowledged the impact of the language of instruction on the development of teaching and learning practices (e.g., Adler, 2001; Barwell, 2012; Jorgensen, 2010; Setati, 2005). It is revealing, however, that much of the research on language diversity and mathematics learning is centered on the problems faced by certain groups of "linguistically diverse" students, rather than the opportunities. The increasing amount of studies embedded in the language-asresource approach (e.g., Chitera, 2011; Moschkovich, 2002; Planas \& Civil, 2013; Turner \& Celedón-Pattichis, 2011) marks the start of a closer look at possibilities and challenges. I argue that to better understand the dynamic nature of learning opportunities, 
there is a need to relate the language-as-resource approach to the exploration of students' difficulties with (one of) their languages while doing mathematics. A shift is required from the language-as-resource approach to a more specific focus on the creation of learning opportunities in classroom situations in which some of the students experience language difficulties, which may be either real or presumed.

In line with the studies in the field that have shown some of the advantages of bilingualism (e.g., Chval \& Khisty, 2009; Clarkson, 2007; Ní Ríordáin \& O’Donoghue, 2009; Parvanehnezhad \& Clarkson, 2008), this article attempts to offer a favorable view of bilingualism from the perspective of its relationship with the creation of opportunities that may be beneficial to mathematics learning. I exemplify language difficulties in bilingual mathematics classrooms that have been revealed not only to not be counterproductive but also to support the learning of students whose home language is not the language of instruction. In what follows, I give an overview of my research context and approach to mathematics education. Before I discuss the methods, I summarize some studies that are influential in terms of their impact on my work on mathematics learning by bilingual students. The central part of the article is the presentation of results, with three examples from three instances of small-group work. Much of what is positive about the examples is that the students use their languages in ways that reveal their participation in solving the tasks given by the teacher, although interruptions in the mathematics may happen.

\section{My research context and orientation}

In Catalonia, an autonomous region in northeast Spain, there is a huge Latin American community with groups of children who speak distinct varieties of Spanish and are diverse from a geographical perspective (Huguet \& Janés, 2008). I use the term Latin American in the specific sense of a construct that designates the language and immigrant experiences of people who come from, or whose families come from, American countries in which Spanish is the language of instruction at school. Although there are several causes that make Latin American children not a mainstream group in the Catalonian school system, the fact that Catalan is the only official language of instruction is decisive. Of course, not all Spanishspeaking students in Catalonia are Latin American. Elsewhere (Planas, 2011), I have argued that either immigration or a recent immigrant background make Latin Americans different from the students whose home language is Spanish but who have been socialized since very young ages in both Catalan and Spanish.

Catalan is spoken by most of the people in Catalonia as either a dominant or a second language. It has largely been given a strong role in the construction of the Catalan cultural identity, and now it has reached a high status. The role and use of Spanish goes beyond the valorization of the language per se and points to power relationships in Catalan society. Some implications of minority language maintenance include institutional support toward using Catalan instead of Spanish or any other language in public documents as well as school written materials. Classroom materials are mediated by the language policy in the country in that they are elaborated in one language only and the option of providing additional translated versions is not considered. In this context, my overall approach is influenced by the sociology of language, that is, an understanding of the fact that social discourses and social organization are central to language use (Makoni \& Pennycook, 2005). 
Although teachers are expected to use only Catalan in their lessons, there is room for resistance on both the side of the teachers and that of the students. Planas (2007) gives evidence of students resisting the current language policy and trying to carry out flexible language practices. Students need to be aware of which language to choose in which situation and how, but more importantly, they need to be active in their learning process by experimenting with the use of their languages. And they do so in different ways. From observation of several lessons in the last decade, I can say that the combined use of Catalan and Spanish in multilingual classrooms is frequent, though with different intensity levels and often in interaction with other languages. This means that in practice, language-aspolitical and language-as-resource (for theoretical elaboration on these metaphors see Planas \& Civil, 2013) serve as complementary working hypotheses of what happens in classrooms in which at least one of the speakers (may) use two or more languages.

\section{Bilingual learners of mathematics}

The pioneering survey by Austin and Howson (1979) drew attention to language as a key issue in the learning of mathematics. Not so many years ago, Pimm (1987) concluded that language is one of the major areas for research to be conducted in mathematics education. The expansion and redirection of the views by Austin and Howson, and by Pimm, towards issues of multilingualism has been clearly put into words by Morgan (2007), who argues that studying language and communication in mathematics education implies studying multilingualism (a reality with the presence of two or more languages), and vice versa.

Bautista, Mulligan, and Mitchelmore (2009) have pointed to multilingual learners of mathematics showing interpretation problems in the language of instruction, exacerbated by cultural misunderstandings and barriers. Other studies have supported this, such as Jones (2009) and Ní Ríordáin and O’Donoghue (2009), which investigated bilingual students' mathematics learning from the perspective of a weak knowledge of the language of instruction interfering with successful performance. Although these studies (including Planas \& Civil, 2002) recognize that language is not the only challenge facing mathematics learners, they keep the focus on what children cannot do and/or are not expected to do. From my observation and reading, I have evolved towards the claim by Clarkson (2007):

Bilingual students have, at times, been thought to be at a disadvantage in learning mathematics because of an assumed interference between their two languages. (...) this is a naive view to take. Although some bilingual students do have a harder time, others seem to be at an advantage. (p. 191)

Moschkovich (2002) has expressed keen concern with understanding the experiences in the mathematics learning of bilingual Latino/a students in the US school system. She has identified practices of code-switching in which students spontaneously combine their languages in the mathematics classroom. In Moschkovich (1999), some other practices are shown to be effective in keeping the focus on mathematics when difficulties with the language of instruction appear. Practices of revoicing are identified in the discourse of an English-dominant teacher who works with the use of informal mathematical vocabulary by Latino/a students, and models appropriate mathematical terms in her talk. Revoicing by students in small groups, to clarify meanings and words used by others, has been also documented in the field. In a bilingual classroom setting, Planas and Morera (2011) illustrate 
instances of group work where some students restate some of their peers' comments in more academic language, without hindering the mathematical discussion being carried out.

Civil (2012) has also added important insight into the classroom experiences of Latino/a students learning mathematics in the context of restrictive language policies in the US. She has focused on the implications of those policies for students whose home language is not the language of instruction, and who come from "non-dominant" groups. Civil argues that much of the Latino/a students' mathematical thinking is missed if the teacher and other students limit communication to English only. Yet, resisting the language policies in place

(through codeswitching, revoicing, and more generally by (encouraging) talking

mathematics in either language) provides more resources and learning opportunities. Moreover, she mentions the phenomena of resistance and caution of Latino/a students in the use of their home language. Most of them have a strong commitment to learn as much English as they can at school in the shortest time possible so that they can get on with their lives as members of an Englishspeaking society. With data from South Africa, Setati (2008)

has reached similar findings about multilingual students who are concerned with not learning as much English as they should if they use their home languages in the classroom. Along with language practices, the role of specific mathematical practices in the schooling of multilingual students is essential. For settings where the teacher is monolingual (so that code-switching, revoicing, etc. is hardly modeled in the teaching), Barwell (2009) brings up the question of what can be done to facilitate the participation of multilingual students in mathematics. For both monolingual and multilingual teachers, he claims that a major challenge is to keep the twofold focus on mathematics and language through classroom norms that move actions in the direction of autonomous and reflective learning. Talking, arguing, and explaining are quality practices that let the students gain autonomy from the teacher and become active in communicating their mathematical thinking in either language:

... there is a difficult balance to be struck between attention to mathematics and attention

to language, where the latter includes not only vocabulary, but also broader aspects of language such as mathematical ways of talking, arguing and explaining. (p. 7)

In short, the analysis of literature points to three concerns for interaction with the understanding of mathematics learning by bilingual students: language policy(what counts as proper action), language practices (what counts as proper communication), and mathematical practices (what counts as proper mathematics). Although my focus in this article is not on language policy, and I do not pretend to develop theory to address the politics of language practice, the strong relationship between questions of practice having an influence on initiatives for policy, and vice versa, cannot be forgotten. The creation of learning opportunities requires a search for possibilities of resistance to restrictive policies and practices involved in the bilingual classroom. Embedded in this search is the assumption that language use may be favorable or unfavorable to learning depending on how it is situated in relation to mathematics and social discourses of success (Setati \& Adler, 2000).

4 Mathematics learning opportunities and language-as-resource

Now, I directly address the notions of mathematics learning opportunities and languageasresource. The two of them are central to the claims that are made throughout the article, 
and their close interrelation constitutes the core of what I see as my contribution to the development of theory in the field: the existence of rigid language practices that are critical to the students' mathematical participation in the multilingual classroom, and on the other hand, the existence of flexible language practices that promote such participation along with the generation and exploitation of mathematics learning opportunities. Unlike other studies on mathematics education and language diversity, which have reported the difficulties and obstacles that arise in learning and teaching due to bilingualism in the classroom, a change of focus is proposed to put opportunities at the front of the discussion.

Similarly to Yackel (2001) and Yackel, Cobb, and Wood (1991), I refer to the notion of mathematics learning opportunities as a way to link the social aspects of classroom activity to the students' conceptual development around mathematical ideas. The classroom activity and its broader system of practices are decisive because it may happen that the created opportunity is not exploited by the students and does not lead to the construction of mathematical knowledge. Although unexploited learning opportunities are essential to any learning process and some of them come from the circumstance of students not paying attention to all opportunities, it is still relevant to investigate why, how, and which (un)exploited opportunities arise in distinct classroom settings. From a social perspective, the possibilities for the creation and exploitation of mathematics learning opportunities are influenced by circumstances that go beyond the control and behavior of the individuals interacting in the classroom. As stated by Yackel et al. (1991):

As the children work together and strive to communicate, opportunities arise naturally for them to verbalize their thinking, explain or justify their solutions, and ask for clarifications (p. 401) (...) Spoken language is obviously one important means of communication in this process. (p. 402)

In the multilingual mathematics classroom, it is reasonable to examine the role and use of the students' languages in the teaching and learning, as well as their impact on the creation and exploitation of mathematics learning opportunities. Both the creation and exploitation of opportunities imply more than individual issues of attention and ability. One of the issues at stake concerns the social recognition given to the spoken languages in the classroom (Setati, 2005) together with the practical use given to them in the interaction (Moschkovich, 2002). The students who take profit from certain opportunities are not always those with more mathematical knowledge than the other children, but those whose dominant language and participation are prioritized in group interaction.

There are learning opportunities whose unexploited nature can be explained in terms of the unexploited use of the students' languages as a tangible resource in the classroom (Planas \& Civil, 2013), while other learning opportunities are not even generated due to the same reason. This is why, to understand the link between activity in the multilingual classroom and conceptual development, it is necessary to introduce the definition of a languagespecific notion of mathematics learning opportunities. I bring up the notion of language-asresource to represent a language-specific orientation consisting of the use of the students' languages in classroom activity in ways that allow and maximize the generation and exploitation of mathematics learning opportunities, hence the meaning as a potential for thinking and doing, and particularly for learning and teaching mathematics. It is a notion grounded in the work on language planning by Ruiz (1984). Although the writing by Ruiz 
is 30 years old, his description of two competing orientations, language-as-problem and language-as-right, and his proposal of language-as-resource as an alternative, are still valid:

[Language-as-resource] can have a direct impact on enhancing the language status of subordinate languages; it can help to ease tensions between majority and minority communities (p. 25) (...) perhaps the best approach would be to encourage the compilation of a strong literature with an emphasis on language as a resource. (p. 28)

\section{Question and methods}

The data reported in this article come from a major project that started in 2007, whose first part was finished in 2011. The main goal was to explore how Latin American students use their two languages-Spanish and Catalan-to support their mathematics learning in small groups with other students who are either Spanish- or Catalan-dominant. The core questions are as follows: How do Latin American students use their languages in small-group discussions, and how is this linked to the creation of mathematics learning opportunities?

For 5 years, lessons from mathematics classrooms in three public secondary schools were video-recorded and transcribed, and the transcripts were analyzed in conjunction with the video recordings. The schools and the classrooms were chosen based on my regular collaboration with the teachers in a professional development working group (for details of the Critical Mathematics Education Group, see Planas \& Civil, 2009). For each school year, no more than two Latin American students from different classrooms were selected. As all the lessons were planned to spend time on small-group work, there was an initial video recording of the whole class, with a second camera focused on the group with the selected student in that classroom. The videos and transcripts were partitioned on the basis of which mathematical task was being examined in the group. A similar orchestration and sequence of tasks in all the lessons were decided on together with the teachers. The topic was variable depending on the school year and the teachers who were participating at that time. All the teachers prompted the students to work in small groups to solve the tasks and for the groups to report their decisions to the class in the final discussions. Moreover, in the context of the professional development collaboration with the teachers, we agreed to make explicit the importance of norms of explaining and justifying procedures, strategies, and solutions (Yackel, 2001) at different moments of the lessons.

The students in the study, with ages between 12 and 16, came from Argentina, Colombia, Ecuador, Mexico, Peru, and Venezuela. Although all students in regular classrooms are expected to have good knowledge of Catalan (otherwise, they remain in the "special classes" for students who are labeled as "Catalan language learners"; see Planas, 2007, for details of the local school system), there is a considerable diversity in the proficiency levels in the language of instruction. As reported by their teachers and confirmed in the videos of the lessons, some Latin American students were more bilingual than others. What was decided in the project was to include only regular Catalan and Spanish bilingual classrooms (not "special classes"), in urban schools from predominantly Latin American neighborhoods. In each classroom, over a quarter of the students was Latin American or children of Latin American families. Classrooms with students whose dominant language was neither Catalan nor Spanish were included for the first year, after which they were discarded. The high number of languages (e.g., Arabic, Urdu, Punjabi, and Tagalog) was reduced to facilitate a 
focused understanding of a "case" of multilingual classrooms in which language tensions tend to remain invisible due to the supposed similarities between Catalan and Spanish.

The students had had different experiences and had been exposed to different norms with respect to the use of Catalan and Spanish. In spite of this, however, I assumed that language policy had an influence on all the classrooms and students. On the other hand, the selected students were aware of having been chosen for an investigation. I asked them to volunteer to participate in a study that sought a better understanding of mathematics learning. I made it clear that language was an issue and told them that Catalan-dominant speakers had been asked to volunteer in a prior study (see the interviews with Catalan-dominant students in Planas, 2007). I conducted informal interviews with those students who wanted to know more about me to explain my interest in learning. A total of nine Latin American students volunteered, none of whom participated in the study for more than one school year. This is a low number compared with the Latin American population in the classrooms and the 20 students who were approached over the 5-year period. Nevertheless, in light of the emergence of a massive amount of data, the end number of students was considered sufficient to complete the initial period in the project.

I did not plan to collect data aimed at identifying what students knew about the contents in the lessons in advance. In the absence of comparable before-and-after data, concrete contents of learning could not be inferred. This was not a limitation, though, as the intention was to relate the creation of mathematics learning opportunities with the persistence of the focus on mathematics in the talk. Within the framework of social theories and taking the metaphor of changing participation as learning (Sfard, 2008), I interpret mathematics learning opportunities as an extension of opportunities for mathematical participation. Following the participationist approach by Sfard and Kieran (2001), the small group may be taken as a rich collaborative site in which individual learning is likely to occur. Thus, examining the details of practices among students in small groups is a "natural" way of looking for evidence of explicit learning opportunities and potential learning. Also, it is important to note that data were not collected in order to investigate Latin American students as cases, nor did I strive to make any comparisons across individual trajectories.

In the following section, I discuss three language practices that came from the analyses of several classroom instances with the participation of the focal students: (1) caution with mathematical vocabulary, (2) invention of terms, and (3) word-for-word translation. These are not exclusive categories, as, for example, caution with vocabulary and invention of terms may appear at the same time. One example is chosen to represent each practice and some of its effects in terms of either created or inhibited learning opportunities. The three examples provide a view of some possibilities for language use that may be beneficial to mathematics learning. Even the example with an interruption in the focus on mathematics prompts us to reflect on found and missed language practices. With the choice of two examples related to the creation of learning opportunities and one related to the obstruction of such opportunities, I show the qualitative approximate ratio of 2:1 between "favorable" and "notso-favorable" instances throughout the investigation. The importance of this quantitative claim, however, needs to be put in context due to the procedure for the selection of students. They were selected on the basis of their expression of interest in the research, and by doing so the condition of powerful and curious learner was somehow facilitated. 
I will begin by analyzing instances of small-group work that help to illustrate language and mathematical practices in support of understanding algebra. A third instance provides a contrasting finding, where the assumption of language difficulties leads to a temporary interruption in the focus on mathematics. The three instances exemplify the interaction between language use and creation of learning opportunities in group work. They occur in three different classrooms from three schools, with students aged 13 and 14.

For this article, I have selected short instances from lessons with the same topic: the introduction to the language of algebra. All three lessons refer to formulating and explaining the conversion of sentences from Catalan into algebra (considering algebra essentially as a language) and vice versa. As expected, formulation and explanation were confirmed as sociomathematical norms that required a great deal of negotiation and prompted participation. The corresponding videos and transcripts were divided into instances based on which sentence was being discussed in the group. In all three classrooms, there had been a prior lesson for the students to get familiarized with the language of algebra. That lesson was to be an addition to many other occasional encounters with algebra. Students aged 13 and 14 in my context are expected to have interpreted and used letters as symbols to formulate mathematical statements that represent situations and relationships, as it is actually expressed in curricular documents and common textbooks.

The instances below are representative of what was found at various moments of group work in several lessons. The three selected examples represent only a few of the several instances in which more than one language intervenes in the resolution of the mathematical task. They do not summarize in a particular statistical way the language practices within the broader set of data. However, they are said to be representative with respect to the general phenomenon of mathematics learning opportunities that can be created as a result of the use of the students' languages in group interaction. Other language practices could have been chosen instead, but caution with mathematical vocabulary, invention of terms, and wordfor-word translation have been thought of as sufficient for an adequate and significant understanding of the phenomenon regardless of the specificity of the curricular domain. It is difficult to know the extent to which these language practices are mathematically contentbased, but the three of them were identified in other lessons with different curricular domains like decimal arithmetic and space geometry. Moreover, they are practices that include largely documented forms of language alternation in multilingual settings like codeswitching, transfer, and languageswitching (Setati \& Adler, 2000).

For each example of practice, I summarize the analysis in two stages, beginning with the identification of a language practice and continuing with what may be regarded as created or inhibited mathematics learning opportunities. The first and second instances show that knowledge of Catalan is required at different points in the group work, and that difficulties with Catalan serve as an initiator for expanding mathematical reasoning. The creation of mathematics learning opportunities is facilitated when Latin American students who face either real or presumed language difficulties keep the focus on mathematics in the talk. Conversely, the third instance shows an experience of language difficulty that leads to a change in the focus of the discussion from mathematics to Catalan. Although the interruption of the mathematical discussion does not last for more than a few minutes, it is still important that it happens. A researcher looking at this third instance may identify 
learning opportunities, but the point is that the students do not treat them as opportunities for mathematics learning. The research was not planned to exhaustively conclude about the identification and exploitation of learning opportunities on the part of the students. Nevertheless, when a student does not publicly elaborate on the mathematical ideas that emerge in the interaction, and progress is not observed in the resolution of the task, it can be inferred that an opportunity has not been taken.

\subsection{Caution with mathematical vocabulary}

The instance in Excerpt 1 shows one student from Ecuador, Roberto, discussing with his Catalan dominant peers, Joana and Miquel, the conversion of $2 x+1$ into Catalan (which henceforth appears in italics in all excerpts to distinguish it from sentences (originally) in Spanish). After some individual work, Joana and Miquel both come to an arithmetical interpretation, "odd number," which they have written in Catalan, nombre senar. There is no evidence of these students having seen the possibility of a geometrical interpretation. On the other hand, Roberto says not to have remembered the Catalan term for "odd number," and points to it as the cause of his geometrical reasoning. In his notebook, near the Catalan sentence that he reads (see Excerpt 1), he has drawn a rectangle with two sides of length $\mathrm{x}$ and 2 , near a square with side 1 . The drawing represents the area of the rectangle $(2 \cdot x)$ together with the area of the square $(1 \cdot 1)$. Even though he graphically represents four equal sides for the square, he also marks the length for two of the sides, probably in preparation for the operation needed to measure the area.

\section{Excerpt 1}

Roberto: ¿Tú que escribiste para este otro? [What did you write for this one $\{2 \mathrm{x}+1\}$ ?]

Joana: Un número impar. [An odd number]

Roberto: ¿Pero qué escribiste en la hoja? [But what did you write on the sheet?]

Joana: Esto, un nombre senar. [This, \{reading\} an odd number]

Roberto: Senar... no me acordaba. [Odd... I could not remember]

Miquel: Jo també he posat nombre senar. Tu què has posat? [I have also written odd number. What have you written?]

Roberto: Rectángulo de... costat dos i quadrat de costat u. [Rectangle with... \{reading\} side two and square with side one]

Miquel: A veure, com? [Let's see, how?]

Roberto: Es que no me acordaba de senar. [Because I couldn't remember odd]

Miquel: Pues haber puesto imparell. [So you could have taken \{another Catalan word for odd \} odd]

Roberto: No sé, me sonaba mal. [Not sure, it sounded like bad]

Joana: Però és bona idea... És com si fossin dues àrees. [But it's a good idea... It's as if they were two areas] 
Roberto: És que són dues àrees! [It's because they are two areas!]

Miquel: Et sonava malament? [It sounded wrong to you?]

Joana: Si li sona bé, no ho fa. [If it sounds right to him, he doesn't do it]

Roberto: Miro las áreas del dos equis y del uno. [I look at the areas for two $\mathrm{x}$ and for one]

A few minutes before in the same lesson, the three students had translated 2 xinto nombre parell, which in Catalan means "even number," and none of them had developed any geometrical interpretation. This fact gives credibility to the scenario of Roberto first trying to find the Catalan word for odd number in order to provide an arithmetical interpretation. The concern with specific vocabulary may have constrained the development of the arithmetical meaning for $2 x+1$ (which is achieved with the participation of Joana and Miquel in the group). I refer to "caution with mathematical vocabulary" because Roberto says to know one candidate for odd, imparell, but intentionally he prefers not to use it ("Not sure, it sounded like bad"). In opposition to what happens with parell, which is the only Catalan word for even, there are two Catalan terms for odd: senar and imparell. Additional trouble with the Catalan words for odd is that one of them (imparell) looks more Spanish than the other (the Spanish term for odd is "impar"). Huguet (2007) elaborates on explanations for some Catalan-dominant speakers choosing vocabulary in ways that make their home language look linguistically distant to Spanish. Drawing on this, it may have happened that Roberto remembers that there is a "more appropriate" choice than imparell. Being cautious here seems more related to social knowledge of what counts as linguistically appropriate than to mathematical knowledge around the set of meanings for $2 x+1$.

From the perspective of the creation of mathematics learning opportunities, the impact of being cautious with specific mathematical vocabulary is positive for all the students in the group who benefit from the introduction by Roberto of geometrical meanings. The explicit focus on language does not attenuate the mathematical discussion. The three students treat that moment in the conversation as an opportunity for negotiating an alternative meaning for $2 x+1$. It is in this regard that the language and the focus on it becomes a potential resource for expanding mathematics learning.

\subsection{Invention of terms}

The instance in Excerpt 2 shows two students from Colombia, Juan and Carmen, in interaction with their Catalan-dominant peer, Anna. They are talking about the conversion of the sentence "Addition of two consecutive numbers" (in Catalan on the paper) into an algebraic expression. Unlike the task in Excerpt 1, the translation goes now from ordinary to algebraic language. Anna provides two examples of right answers, $x+(x+1)$ and $(x-1)+x$, but when particularizing with numbers, she chooses noninteger decimal numbers and claims the consecutiveness of 3.5 and 4.5. Juan answers that the two numbers need to be no continuats, which might be literally translated as "noncontinued". Carmen points to the invention by her peer (in mathematics, there is no category of "noncontinued" numbers), but does not give much importance to it. She revoices the invented word and introduces the mathematically correct term ("consecutive") in a way that does not interrupt progress in the task. It is interesting to note that the student who takes responsibility for revoicing is a nonCatalan-dominant speaker who entered the Catalan school system before Juan. 
Excerpt 2

Anna: Sumar dos nombres consecutius... Fàcil, $\mathrm{x}+(\mathrm{x}+1), \mathrm{o}(\mathrm{x}-1)+\mathrm{x}, \mathrm{o} \ldots$ [Adding two consecutive numbers... Easy, $\mathrm{x}+(\mathrm{x}+1)$, or $(\mathrm{x}-1)+\mathrm{x}$, or...]

Juan: Què més? [What else?]

Anna: Puc donar exemples, com $3+5,3.5+4.5 \ldots$ És sumar 1. [I can give examples, like

$3+5,3.5+4.5 \ldots$ It's adding 1$]$

Juan: Sí, sumar 1, però els, los números tienen que ser no continuats, como 3, 4, 5, 6...

[Yes, adding 1, but the, the numbers need to be non-continued, like $3,4,5,6 \ldots$ ]

Carmen: Continuats? Es consecutius! [\{smiles Continued? It's consecutive!]

Juan: Conse... Mira, així ho entendrem millor. 3.5 y 4.5 son continuats. [Conse...

Look, this way we will understand it better. 3.5 and 4.5 are continued]

Anna: Són consecutius per la resta, és 1. [They are consecutive because of the difference, it's 1]

Juan: Però són decimals... son continuats, no es que se siguen. [But they are decimals... they are continued, they don't follow each other]

Carmen: Sí, han de ser consecutius i que... se sigan. [Yes, they need to be consecutive and $\ldots$ follow each other].

Anna: Llavors cap dels decimals va bé. [Then, none of the decimals works]

Juan: Però per què? Perquè no se segueixen. ¡Mira 3.8! [But why? Because they don’t follow each other. Look at 3.8!]

Anna: Pots buscar més... 3.7. [You can look for more... 3.7]

No continuats is a term that reconciles two interests: that of looking like Catalan and that of looking mathematical. Drawing on the conversation that takes place, it can be argued that the use of the invented word facilitates the discussion of consecutive numbers being always integers and, overall, the discussion of their substantial property, namely following each other immediately in order (not the difference being 1, as wrongly stated by Anna). The family of meanings that can be attached to "noncontinued" suggests the property of continuity of the number line with all numbers, both integers and those with a decimal expansion other than zero. In fact, after saying, "the numbers need to be noncontinued," Juan starts enumerating a countable set, "like $3,4,5,6 \ldots$," as if being noncontinued was semantically near being countable. From transcript and video data, it is not totally clear, however, what Juan is designating with the invented word, nor is it clear whether he is replacing a Catalan word that he does not know or remember. Whether or not Anna comes to understand the discontinuity that is linked to the notion of consecutive number is not totally clear either. What can be said is that the use of an invented mathematical- and Catalan-looking term does not become the focus of the interaction in the group, but instead turns into a resource for going on with the mathematical discussion. 
From the perspective of the creation of mathematics learning opportunities, the impact of having invented a word is favorable for the students in the group. The generation of learning opportunities is possible because the three students treat the invented word at the same time as mathematically inspiring and problematic. A language invention has been conducive to generating mathematical discussion, presumably more than the use of the correct term would have been in that moment of group work. The view of consecutive numbers as "noncontinued" expands the elaboration of correct mathematical meanings. Moreover, the invented word somehow serves as an ostensive definition that helps to explain the notion of consecutive number by pointing out sets of numbers that have a particular property.

\subsection{Word-for-word translation}

The instance in Excerpt 3 shows one student from Colombia, Jorge, in interaction with his Catalan dominant peer, Pol. They are talking about the conversion of the sentence "Relationship between the perimeter and the radius of a circumference" (in Catalan on the paper) into an algebraic expression. The third student of this group did not attend school that day. Most of the interaction below between the two students is marked by the wordfor-word translation from Catalan to Spanish. When Jorge asks Pol whether relationship is division, the question is interpreted as requiring literal translation and there are no additional efforts to convey mathematical meaning. In school mathematics, the notion of relationship is certainly ambiguous and abstract. It is tied to the ways in which different mathematical terms may be taken together, which in turn tends to be developed by many students through operations (Mason, 1996). It is therefore not surprising that Jorge brings up the idea of division. On the other hand and at this stage of the introduction of algebra, the task itself is ambiguous in that it asks to algebraically express a constant, $2 \pi$. The understanding of such constant as a particularization of the notion of algebraic expression is not immediate.

\section{Excerpt 3}

Jorge: ¿Relación es división? [Relationship is division?]

Pol: No! Relació és relación. [No! Relationship is relationship]

Jorge: Ya pero... ¿es división también? [I know, but... is it also division?]

Pol: No, solo es relación. [No, it only is relationship]

Jorge: Entonces, ¿cómo sabemos qué es relación? [So how do we know what relationship is?]

Pol: Això és el que et pregunten. Ho has de buscar. [This is what they ask you. You have to look for it]

Jorge: No ho entenc. [I don't understand it]

Pol: Saps les altres paraules? Perímetro... [You know the other words? Perimeter...]

Jorge: Perímetro, radio, circunferencia... [Perimeter, radius, circumference...]. 
Pol: D'acord. Jo he agafat la fórmula del perímetre que és $2 \pi r$, i després he agafat $r$. [Okay. I have taken the formula of the perimeter, which is $2 \pi r$, and then I have taken $r$ ]

Jorge: I què? [So what?]

Pol: Ja està. Busques la relació, que és $2 \pi$. [That's all. You look for the relationship, which is $2 \pi$ ]

Jorge: Pues relación es división... [Then relationship is division...]

Pol: No tornis a començar! [Don’t start again!]

By understanding communication as translation, the focus on language is kept far from the focus on mathematics. In this instance, word-for-word translation does not generate additional meaning. Despite formulating a correct response, there is no evidence of either Pol or Jorge seeing the notion of relationship as something more general than specific arithmetical operations. One of the created difficulties here has to do with assuming an explanatory function of literal translation, instead of providing mathematical explanations. Translation is imposed on Jorge when the practically identical Catalan and Spanish terms for relationship are put together by Pol, along with the translation for perimeter, radius, and circumference. Although it may not be deliberate, translation is given a function of reducing communication by giving more emphasis to language than to mathematics. Pol may know that explanations are valuable in the classroom, but he may not know how to do it for this task. Together with an insufficient mastery of the mathematics in the task, efforts in the direction of providing explanations may be hindered by a constraining use of translation.

The language practice of word-for-word translation has appeared in the analyses of other instances throughout the study. Unlike the example in Excerpt 3, it has often served to illustrate translation as communication and support of learning opportunities. Literal translation has been shown to arise in the interplay between language difficulties and mathematical discussion. What may explain the contrasting results for the same language practice is that word-forword translation is not always driven by one of the students with little regard for the other to the extent that one participant imposes her/his plans over the actions and requirements of others. A parallelism can be drawn with the language practices of caution and invention. There are instances, for instance, in which the introduction of an invented word finds a rather hostile reaction that leads the students to replace the mathematical discussion with considerations of what is not allowed in language. Again, when this happens, the change in the focus is imposed by one student on another. It is often clear to determine who the initiator is, but it is not so clear to determine the support intensity or continuity that $\mathrm{s} / \mathrm{he}$ receives from other participants in the group. At this stage of the project, it cannot be said that imposition in group interaction is merely one manifestation of language hierarchy. Other social issues and the contents in the talk may be importantly at play. What situations of imposition come down to in the end is the role of both language use and language users in the development of mathematical participation.

7 Conclusions and contribution to research

My study is in mathematics education and, consequently, I have examined mathematics learning opportunities coupled with language practices rather than language learning 
opportunities. The discussions in the documented episodes, however, are also rich in the learning of technical vocabulary and academic language. They show how mathematical contents and the language used to communicate them are constructed in interaction by students in small groups in which the task is introduced as mathematical. Elsewhere (Planas, 2011), I have indicated the quality of collaborative classroom settings of peer discussion, in comparison to traditional classroom settings of individual work, from the perspective of the opportunities for talking, communicating, and modeling academic language.

My main argument has been that the orientation of language-as-resource makes sense in the analysis of the bilingual mathematics classroom. The first two examples support the view that certain language difficulties contribute to generating mathematics learning opportunities provided that the mathematical discussion is not replaced by a unique focus on language. I have also presented a third example where the focus on mathematics is not maintained. With only one contrasting example, I have sought to indicate that instances of language difficulties with interruptions in the mathematics are relevant but not frequent. Moreover, the three examples in conjunction have offered a glimpse into the tension between meeting the language needs of the classroom and promoting the mathematical goals of the learning.

According to my analysis, mathematics learning opportunities in the bilingual classroom take on the form of opportunities for mathematical participation in flexible language practices. What affords the generation of certain mathematics learning opportunities is the broader opportunity for meaningful language use and explicit resistance to language policy. By coming up to a reconceptualized notion of mathematics learning opportunities in terms of its relationship with language use, the notion of mathematics learning is consequently to be reexamined as dependent on the contributions of language users. Language use is relevant in uncovering not only the creation of learning opportunities but also its treatment as such by the students (and the teacher), and its progress toward learning. In brief, my findings point to the exploration of language use as a way to uncover how opportunities for participation may be constituted as conducive to learning, particularly for those students whose dominant language is different from the language of instruction.

What still remains to be understood is the variable nonstructural effect of similar language practices on the students' mathematical participation by either inhibiting or promoting learning opportunities. I have pointed to the difficulties in preventing the effects of language use and have tentatively suggested that actions of imposition may give rise to effects that are not favorable to learning. Despite the limits given by social dynamics and structures, one way to reduce imposition could be by means of explicitly establishing classroom norms on the flexible use of languages in the course of mathematical activity. Learning opportunities need to be created in conjunction with classroom norms, so that when these opportunities are at risk, norms can be revised. We cannot know the real causes behind the imposition in the example with Jorge and Pol, but the explicit teaching of certain norms would have helped. The teaching and learning of norms like "If there is a word that you do not usually use, try to understand its meaning," or "You need time to shift into proper mathematical talk" refer to language and keep the focus on the goals of the mathematics classroom. Such norms cannot remain tacit in practice and need to be invoked while teaching. It is easier for students to choose language practices that have been made explicit to them as the teacher's preference. 
Earlier in this article, I have specified the focus on practices about what counts as proper communication and proper mathematics. I have also specified the strong relationship between practices and policies. At this point of the discussion, it is important to mention the role of classroom and group norms in the policy-practice continuum. Classroom norms, like those exemplified in the paragraph above, may encourage flexible language practices as well as the creation and exploitation of mathematics learning opportunities. But for the consequences in terms of the repeated interaction among particular students, group norms are even more decisive in the classroom organization of my research context. A good example of a group norm in line with the language-as-resource orientation would be the following: "You may react to what has been said by any peer in group work." This idea of direct reciprocity challenges power dynamics in that any student, independently of the dominant language, is allowed to react to the acts of any other student who has interacted with her/him before. Similarly to general classroom norms, group norms which recognize the voice of all potential speakers need to be invoked while teaching as part of the explicit contract in the multilingual classroom.

My examples are Catalan-Spanish, but their value can be interpreted from an international perspective and are expandable with the analyses of language practices from other parts of the world. I see my findings contributing to mathematics education research in two main ways. First, they confirm the relevance of language-as-resource in the understanding of mathematics learning by students whose dominant language is not the language of instruction. Second, they shed light on the connection between the experience of language difficulties and the creation of mathematics learning opportunities. This connection suggests links between two sets of theorization in the field: the research on multilingual mathematics classrooms (Adler, 1997), and the research on mathematics learning opportunities (Yackel et al., 1991). In this respect, systematic research with the design of theory-based learning environments (Cobb et al., 2003) has not yet been done. The development and implementation of design experiments are to be taken seriously into account if we want the story of "linguistically diverse" students to change. Different variations of design experiments might serve as microworlds to inform of language practices and sociomathematical norms involved in the generation of learning opportunities in the multilingual mathematics classroom.

\section{Acknowledgments}

Grants number EDU2009-07113 and EDU2012-31464, funded by the Spanish Ministry of Economy and Competitivity.

\section{References}

Adler, J. (1997). A participatory-inquiry approach and the mediation of mathematical knowledge in a multilingual classroom. Educational Studies in Mathematics, 33, 235-258.

Adler, J. (2001). Teaching mathematics in multilingual classrooms. Dordrecht: Kluwer Academic Publishers.

Austin, J. L., \& Howson, A. G. (1979). Language and mathematics education. Educational Studies in Mathematics, 10, 161-197.

Barwell, R. (2009). Multilingualism in mathematics classrooms: An introductory discussion. In R. Barwell (Ed.), Multilingualism in mathematics classrooms: Global perspectives (pp. 1-13). Clevedon: Multilingual Matters. 
Barwell, R. (2012). Heteroglossia in multilingual mathematics classrooms. In H. Forgasz \& F. Rivera (Eds.), Advances in Mathematics Education. Toward equity: gender, culture, and diversity (pp. 315-332). New York: Springer.

Bautista, D., Mulligan, J., \& Mitchelmore, M. (2009). Young Filipino students making sense of arithmetic word problems in English. Journal of Science and Mathematics Education in Southeast Asia, 32(2), 131160.

Chitera, N. (2011). Language of learning and teaching in schools: An issue for research in mathematics teacher education? Journal of Mathematics Teacher Education, 14(3), 231-246.

Chval, K. B., \& Khisty, L. L. (2009). Bilingual Latino students, writing and mathematics: A case study of successful teaching and learning. In R. Barwell (Ed.), Multilingualism in mathematics classrooms: Global perspectives (pp. 128-144). Clevedon: Multilingual Matters.

Civil, M. (2012). Opportunities to learn in mathematics education: Insights from research with "nondominant" communities. In T. Y. Tso (Ed.), Proceedings of the 36th Conference of the International Group for the Psychology of Mathematics Education (Vol. 1, pp. 43-59). Taipei: PME.

Clarkson, P. C. (2007). Australian Vietnamese students learning mathematics: High ability bilinguals and their use of their languages. Educational Studies in Mathematics, 64, 191-215.

Cobb, P., Confrey, J., diSessa, A., Lehrer, R., \& Schauble, L. (2003). Design experiments in education research. Educational Researcher, 32(1), 9-13.

Huguet, À. (2007). Language use and language attitudes in Catalonia. In D. Lasagabaster \& À. Huguet (Eds.), Multilingualims in European bilingual contexts: Language use and attitudes (pp. 17-39). Clevedon: Multilingual Matters.

Huguet, À., \& Janés, J. (2008). Mother tongue as a determining variable in language attitudes: The case of immigrant Latin American students in Spain. Language and Intercultural Communication, 8(4), 246260.

Jones, D. V. (2009). Bilingual mathematics classrooms in Wales. In R. Barwell (Ed.), Multilingualism in mathematics classrooms: Global perspectives (pp. 113-127). Clevedon: Multilingual Matters.

Jorgensen, R. (2010). Language, culture and learning mathematics: A Bourdieuian analysis of indigenous learning. In C. Wyatt-Smith, J. Elkins, \& S. Gunn (Eds.), Multiple perspectives on difficulties in learning literacy and numeracy (pp. 314-329). Dordrecht: Springer.

Makoni, S., \& Pennycook, A. (2005). Disinventing and (re)constituting languages. Critical Inquiry in Language Studies, 2(3), 137-156.

Mason, J. (1996). Expressing generality and roots of algebra. In N. Bednarz, C. Kieran, \& L. Lee (Eds.), Approaches to algebra (pp. 65-86). Dordrecth: Kluwer Academic Publishers

Morgan, C. (2007). Who is not multilingual now? Educational Studies in Mathematics, 64, 239-242.

Moschkovich, J. N. (1999). Supporting the participation of English language learners in mathematical discussions. For the Learning of Mathematics, 19(1), 11-19.

Moschkovich, J. N. (2002). A situated and sociocultural perspective on bilingual mathematics learners. Mathematical Thinking and Learning, 4(2-3), 189-212.

Ní Ríordáin, M., \& O’Donoghue, J. (2009). The relationship between performance on mathematical word problems and language proficiency for students learning through the medium of Irish. Educational Studies in Mathematics, 71, 43-64.

Parvanehnezhad, Z., \& Clarkson, P. C. (2008). Iranian bilingual students reported use of language switching when doing mathematics. Mathematics Education Research Journal, 20(1), 52-81.

Pimm, D. (1987). Speaking mathematically: Communication in mathematics classrooms. London: Routledge and Kegal Paul.

Planas, N. (2007). The discursive construction of learning in a multiethnic school: Perspectives from nonimmigrant students. Intercultural Education, 18(1), 1-14.

Planas, N. (2011). Language identities in students' writings about group work in their mathematics classroom. Language and Education, 25(2), 129-146.

Planas, N., \& Civil, M. (2002). Understanding interruptions in the mathematics classroom: Implications for equity. Mathematics Education Research Journal, 14(3), 169-189.

Planas, N., \& Civil, M. (2009). Working with mathematics teachers and immigrant students: An empowerment perspective. Journal of Mathematics Teacher Education, 12(6), 391-409.

Planas, N., \& Civil, M. (2013). Language-as-resource and language-as-political: Tensions in the bilingual mathematics classroom. Mathematics EducationResearch Journal. doi:10.1007/s13394-013-0075-6. 
Planas, N., \& Morera, L. (2011). Revoicing in processes of collective mathematical argumentation among students. In M. Pytlak, E. Swoboda, \& T. Rowland (Eds.), Proceedings of the 7th Congress of the European Society for Research in Mathematics Education (pp. 1380-1389). Rzeszów: ERME.

Ruiz, R. (1984). Orientations in language planning. NABE Journal, 8(2), 15-34.

Setati, M. (2005). Learning and teaching mathematics in a primary multilingual classroom. Journal for Research in Mathematics Education, 36, 447-466.

Setati, M. (2008). Access to mathematics versus access to the language of power: The struggle in multilingual mathematics classrooms. South African Journal of Education, 28(1), 103-116.

Setati, M., \& Adler, J. (2000). Between languages and discourses: Language practices in primary multilingual mathematics classrooms in South Africa. Educational Studies in Mathematics, 43, 243-269.

Sfard, A. (2008). Thinking as communicating: Human development, the growth of discourses, and mathematizing. Cambridge: Cambridge University Press.

Sfard, A., \& Kieran, C. (2001). Cognition as communication: Rethinking learning-by-talking through multifaceted analysis of students' mathematical interactions. Mind, Culture, and Activity, 8(1), 42-76.

Turner, E. E., \& Celedón-Pattichis, S. (2011). Mathematical problem solving among Latina/o kindergartners: An analysis of opportunities to learn. Journal of Latinos and Education, 10(2), 146-169.

Yackel, E. (2001). Explanation, justification and argumentation in mathematics classrooms. In M. van den Panhuizen-Heuvel (Ed.), Proceedings of the 25th conference of the International Group for the Psychology of Mathematics Education (Vol. 1, pp. 1-9). Utrecht: PME.

Yackel, E., Cobb, P., \& Wood, T. (1991). Small-group interactions as a source of learning opportunities in second-grade mathematics. Journal for Research in Mathematics Education, 22(5), 390-408. 